\title{
Ozone therapy as an integrating therapeutic in osteoartrosis treatment: a systematic review
}

\author{
Ozonioterapia como terapêutica integrativa no tratamento da osteoartrose: uma revisão sistemática
}

Ana Paula Anzolin ${ }^{1}$, Charise Dallazem Bertol ${ }^{1,2}$

DOI 10.5935/2595-0118.20180033

\section{ABSTRACT}

BACKGROUND AND OBJECTIVES: Osteoarthrosis affects $85 \%$ of the population over 75 years of age. It is divided into primary and secondary, however despite the knowledge at the molecular level the treatments are not yet fully effective. However, ozone therapy emerges as an alternative therapy, which is low cost and seems effective in the treatment of chronic pain. The objective of this study was to evaluate the current evidence to support or to refute the use of ozone therapy in the treatment of patients with osteoarthritis.

CONTENTS: Systematic review using the keywords "ozone therapy", "ozone”, "osteoarthritis", "arthritis", "randomized", "controlled" and "meta-analysis". The selection of publications was based on inclusion and exclusion criteria. In total, 9 articles were used. Among the 9 articles found regarding ozone therapy in osteoarthritis, 7 of them clearly show the benefits of ozone. The concentrations of ozone used in the studies ranged from $20 \mu \mathrm{g} / \mathrm{mL}$ to $15 \mathrm{~g} / \mathrm{mL}$. The route of administration was intra-articular and rectal insufflation. The frequency of use was, on average, 1 to 3 times a week and the treatment time was between 3 to 4 months in most of the studies.

CONCLUSION: The use of ozone produces clinically relevant benefits in patients with osteoarthrosis. Therefore, ozone therapy in osteoarthrosis represents a low-cost, efficient therapeutic alternative that should be implemented in the country's Public Health, considering the prevalence of the disease.

Keywords: Complementary therapies, Ozone, Osteoarthritis, Therapeutic use.

1. Universidade de Passo Fundo, Programa de Pós-Graduação em Envelhecimento Humano, Passo Fundo, RS, Brasil.

2. Universidade de Passo Fundo, Curso de Farmácia, Passo Fundo, RS, Brasil.

Submitted in January 31, 2018.

Accepted for publication in May 02, 2018.

Conflict of interests: none - Sponsoring sources: none.

Correspondence to:

Campus I, BR 285 - Bairro São José

99052-900 Passo Fundo, RS, Brasil.

E-mail: anapaulasordianzolin@gmail.com

(C) Sociedade Brasileira para o Estudo da Dor

\section{RESUMO}

JUSTIFICATIVA E OBJETIVOS: A osteoartrose atinge $85 \%$ da população com mais de 75 anos. A mesma é dividida em primária e secundária, porém apesar do conhecimento a nível molecular, os tratamentos ainda não são totalmente eficazes. Entretanto, a ozonioterapia, é de baixo custo e parece efetiva no tratamento da dor crônica. O objetivo deste trabalho foi avaliar as evidências atuais que apoiem ou refutem o uso da ozonioterapia no tratamento de pacientes com osteoartrose.

CONTEÚDO: Revisão sistemática, utilizando as palavras-chave: "ozone therapy", "ozone", "osteoarthritis", "arthritis", "randomised", "controlled" e "meta-analysis". A seleção das publicaçóes foi feita a partir de critérios de inclusão e exclusão. Ao total foram utilizados 9 artigos. Dentre os 9 artigos encontrados a respeito de ozonioterapia na osteoartrose, 7 deles mostraram claramente os benefícios do ozônio. As concentraçôes de ozônio utilizadas nos estudos variaram de $20 \mu \mathrm{g} / \mathrm{mL}$ a $15 \mathrm{~g} / \mathrm{mL}$. A via de administração utilizada foi a intra-articular e a insuflação retal. A frequência do uso foi, em média, de 1 a 3 vezes por semana e o tempo de tratamento foi entre 3 a 4 meses na maior parte dos estudos.

CONCLUSÁO: O uso do ozônio produz benefícios clinicamente relevantes em pacientes com osteoartrose, portanto a ozonioterapia na osteoartrose representa uma alternativa terapêutica de baixo custo, e eficiente, que deve ser implantada na Saúde Pública do país, tendo em vista a prevalência da doença.

Descritores: Osteoartrite, Ozônio, Terapias complementares, Uso terapêutico.

\section{INTRODUCTION}

Currently, "degenerative joint disease", is synonymous with the terms osteoarthritis, osteoarthrosis, and degenerative arthritis. The American Rheumatism Association (ARA) and the Brazilian Society of Rheumatology (SBR) have adopted the term "osteoarthritis" instead of degenerative joint disease or osteoarthrosis or arthrosis due to the inflammatory phase of the disease ${ }^{1}$.

The ozone therapy was firstly used in Germany and the Soviet Union in the World War I, spreading to Europe, China, and America. However, it is only legalized in Russia, Cuba, Spain, and Italy. Publications about its use in osteoarthrosis are still limited ${ }^{2}$. The potential of the ozone therapy is presenting good results. A study conducted in Dubai with 220 patients with osteoarthritis, treated during 3 years with intra-articular ozone therapy in a concentration of $20 \mu \mathrm{g} / \mathrm{mL}$, twice a week, showed a significant pain reduction, demonstrating the analgesic effect of ozone in osteoarthrosis ${ }^{3}$. 
The ozone therapy is many times compared with the hyperbaric oxygen chamber (HBOT). However, the intra-articular application of $10 \mathrm{~mL}$ of the ozone gas is more effective, practical, and of low cost, than the hyperbaric chamber ${ }^{4}$.

HBOT is a therapeutic modality that provides pure oxygen (100\%) in a pressurized environment at a level above the atmospheric pressure, and the ozone therapy is a gaseous mixture of about $95 \%$ oxygen and no more than $5 \%$ of ozone 5 . HBOT promotes healing, increases the bactericidal capacity of the neutrophils, the toxic effect on microorganisms, arteriolar vasoconstriction with consequent reduction of the edema, and decreases the ischemic injury and reperfusion, and fractures consolidation time. The angiogenesis stimulation occurs (after 22 hours of the HBOT), as well as collagen formation (after 2 to 4 hours of the HBOT), improving the bone repair process ${ }^{5}$. However, it is only a palliative treatment because, as soon as the patient leaves the chamber, hypoxia restarts in the ischemic areas and the therapeutical effect is minimum and temporary. On the other hand, in the ozone therapy, the ozone triggers a series of mechanisms that lead to the normalization of the oxygen supply for several days with consequent effects, that is, it can correct diseases related to the ischemia, infections, healing delay, and oxidative stress ${ }^{6}$. The ozone therapy has a more prolonged and powerful effect when compared with the HBOT. However, it is necessary to understand when each technique must be applied.

The ozone mechanism of action is not fully known since the specialists who use the ozone therapy are mainly concerned in knowing the therapeutical dose without trying to understand how ozone acts in the biological system ${ }^{6}$.

Physically, ozone dissolves in pure water, and in a well-closed glass bottle, ozone remains active for some days. On the other hand, in contact with oxygen, as soon as it is dissolved in biological water (saline, plasma, lymph, urine) ozone reacts immediately ${ }^{6}$.

It is incorrect to think that ozone penetrates through the skin and/ or the mucosa and remains in the cells because soon after application, ozone no longer exists. That is, ozone reacts with polyunsaturated fatty acids, antioxidants, thiol compounds, as glutathione and albumin, and, depending on the dose, it also reacts with carbohydrates, enzymes, DNA and RNA. All these compounds act as electron donors and suffer oxidation ${ }^{6}$.

According to Anagha et al. ${ }^{7}$, there are three possible mechanisms of action for ozone. The first is related to the inactivation of microorganisms. In the bacteria, the integrity of the cell envelope is interrupted by the oxidation of the phospholipids and lipoproteins. In the fungi, ozone inhibits the cellular growth. In viruses, ozone damages the viral capsid and disrupts the reproductive cycle by interrupting the virus-cell contact with the peroxidation. The second relates to the oxygen metabolism. Ozone therapy causes an increase in the glycolysis rate of red blood cells, raising the 2,3-diphosphoglycerate stimulation, which leads to an increase in the amount of oxygen released into the tissues. There is stimulation in the production of the enzymes that act as free radical sequestrants and protectors of the cellular wall, and vasodilators, such as prostacyclin. The third relates to the activation of the immune system. Ozone administered in concentrations between 30 and $55 \mu \mathrm{g} / \mathrm{mL}$ increases the production of interferon and decreases the tumor necrosis factor and interleukin-2, reducing the intensity of the subsequent immune reactions ${ }^{7}$.
In osteoarthrosis, ozone will activate the cell metabolism, induce the synthesis of the antioxidant enzymes, reduce the synthesis of prostaglandins, improve the functioning of the redox system reducing its oxidative stress, and increase the oxygen supply to tissues by the hemorheological action, vasodilation, and angiogenic stimulation ${ }^{8}$. The advantages of the ozone therapy are the prevention of the oxidative stress, normalizing the levels of the organic peroxide activating the superoxide dismutase 9 . The disadvantages are related to the possibility of over-oxidation, generation of free radicals, and peroxidation of lipids, modifying the membrane permeability and resulting in cell injury or even the cell death ${ }^{9}$. Moreover, ozone can cause risk of embolism if injected directly intravenously; burning sensation in the eyes; difficulty to breathing, and effects as rhinitis, nausea, vomiting, cardiac and respiratory tract problems, and irritation ${ }^{7}$.

In the clinical practice, to ensure safety when working with ozone, it is necessary to use an accurate ozone generator equipped with a standardized photometer that allows to determine the ozone concentration in real time, and to collect a precise volume of gas with a defined ozone concentration, since the total dose is calculated by multiplying the ozone concentration by the volume of gas $^{6}$.

Ozone therapy in osteoarthrosis comes as a low-cost integrative therapy that seems to be effective. It is essential to look for evidence about the effectiveness of the treatment due to the prevalence of the disease. In this context, the objective of the present review is to evaluate the current evidence that supports or refutes the use of the ozone therapy in the treatment of osteoarthrosis.

\section{CONTENTS}

The search was conducted in the following databases: Medline, Pubmed, Cochrane Controlled Trial Register and Cochrane Databases Systematic Reviews (Cochrane Library), using the keywords ozone therapy, ozone, osteoarthritis, arthritis, randomized, controlled and meta-analysis.

All the available studies, in full, with the following information were included:

- Systematic reviews or meta-analysis pre-clinical or clinical randomized controlled trials evaluating the use of intra-articular or rectal ozone therapy in humans and/or animals with osteoarthrosis (or induced osteoarthrosis) in non-surgical treatment;

- Studies that had the assessment of pain intensity as the primary outcome.

The exclusion criteria were studies that evaluated septic arthritis taking into consideration the ozone antibacterial response and studies that evaluated the ozone therapy with another approach than osteoarthrosis.

Of the 70 potentially eligible studies searched in Medline and Pubmed (keywords: ozone therapy AND osteoarthritis; ozone therapy AND arthritis; ozone AND arthritis), only one study included the meta-analysis word. Of the selected studies that were available in full, 18 met the inclusion criteria showing evidence quality. However, in 9 of these articles, there was no direct relation between the ozone therapy and osteoarthritis. Therefore, 9 studies have met the inclusion criteria for the elaboration of the systematic review. Abstracts and comments of the evaluated studies are in table 1. 
Table 1. Summary of the evaluated studies and their differences in the methodology and conclusions

\begin{tabular}{|c|c|}
\hline Authors & Type of studies \\
\hline $\begin{array}{l}\text { Shen } \\
\text { et al. }{ }^{23}\end{array}$ & $\begin{array}{l}\text { Meta-analysis. } 1493 \text { patients included in } \\
\text { the randomization. } \\
\text { Groups: PRP, control group including HA, } \\
\text { placebo, ozone and corticosteroids, by } \\
\text { intra-articular route. }\end{array}$ \\
\hline $\begin{array}{l}\text { Lopes de } \\
\text { Jesus } \\
\text { et al. }{ }^{18}\end{array}$ & $\begin{array}{l}\text { Randomized, double-blind, placebo-con- } \\
\text { trolled clinical trial with } 98 \text { patients who with } \\
\text { symptomatic osteoarthritis of the knee. } \\
\text { Groups: Group } 20 \mu \mathrm{g} / \mathrm{mL} \text { ozone intra-arti- } \\
\text { cular or placebo for } 8 \text { weeks. }\end{array}$ \\
\hline $\begin{array}{l}\text { Feng and } \\
\text { Beiping }^{22}\end{array}$ & $\begin{array}{l}76 \text { patients randomly distributed into two } \\
\text { groups. Group 1: Ozone: injection in the } \\
\text { knee joint cavity, and oral celecoxib and } \\
\text { glucosamine hydrochloride for } 6 \text { weeks; } \\
\text { Group 2: Control: oral celecoxib and gluco- } \\
\text { samine hydrochloride for } 6 \text { weeks. }\end{array}$ \\
\hline
\end{tabular}

Duymus et al. ${ }^{24}$

León Fernández et al. ${ }^{19}$

Hashemi et al. ${ }^{26}$

Vaillant et al. ${ }^{20}$
102 patients divided into 3 groups: PRP Group: received 2 doses of PRP intra-articular injections

HA group: received one single HA dose Ozone group: received 4 doses of ozone. Treatment time: 12 months.

Randomized clinical trial with 60 patients. MTX Group: received MTX, folic acid and ibuprofen

MTXbozone Group: received the same as the MTX group plus ozone by rectal insufflation.

Treatment time: 21 days.

Randomized clinical trial with 80 patients. Group 1: Dextrose, Group 2: Ozone therapy The injections were repeated three times at 10 days intervals. Pain was measured before treatment and 3 months after the intra-articular injections.

Study in rats divided into 4 groups of 45 animals each:

Group 1: Control, only received the stress of the needle in the articular space 3 times/ week;

Group 2: received peptidoglycan-polysaccharide (PG/PS);

Group 3: similar to group 2, but after 10 days of $P G / P S$ they received a $0.2 \mathrm{~mL}$ intra-articulate mixture of ozone/oxygen

Group 4: similar to group 3, but the ozone therapy was replaced by oxygen.

Treatment time: 24 days.

Ozone concentra- Parameters evaluated Conclusions

tion and volume

Concentration not Functional scores

mentioned WOMAC

$20 \mu \mathrm{g} / \mathrm{mL}$

$20 \mu \mathrm{g} / \mathrm{mL}$

$30 \mu \mathrm{g} / \mathrm{mL}, 15 \mathrm{~mL}$

Pain (WOMAC Scale ${ }^{2}$ and VAS)

$25 \mathrm{mg} / \mathrm{L}$ to $40 \mathrm{mg} / \mathrm{L}$ Disease activity, in scaling dose and Health Assessment ascending order Questionnaire Disabiliapplication. $\quad$ ty Index (HAQ-DI) Biochemical markers of the oxidative stress before and after 20 days of treatment.

$15 \mathrm{~g} / \mathrm{mL}$ in the ozone therapy group and dextrose at $12.5 \%$ in the dextrose group.

The ozone dose was calculated based on the weight. The ozone concentration was

$20 \mathrm{mg} / \mathrm{mL}$ and the total administered dose was $80 \mathrm{mg} /$ $\mathrm{kg}$. (GPM).

Functional capacity (Lysholm knee score); Pain intensity (VAS) VAS scales)

Cytokines, nitric oxide and levels of oxidative stress in spleen homogenates and inflammatory processes.
The intra-articular PRP injections were more effective in the treatment of osteoarthrosis of the knee regarding pain, relief and self-reported function improvement at 3,6 and 12 months of follow-up in comparison with other injections, including placebo with saline solution, HA, ozone and corticosteroids.

Pain: (visual analog The study confirms the ozone effiscale) - VAS, Lequesne cacy regarding pain relief, functioIndex, Timed Up and nal improvement, and quality of life Go Test (TUG Test), in patients with osteoarthritis of the SF-36, WOMAC and knee

The ozone intra-articular injection plus oral celecoxib and glucosamine can significantly reduce pain intensity in patients with mild to moderate osteoarthritis and improve their functional state before oral celecoxib and only glucosamine.

In the treatment of mild to moderate knee osteoarthrosis, the PRP presented better results than $\mathrm{HA}$ and ozone injections since the application was enough to provide at least 12 months of daily life activities without pain.

MTXpozone increased the MTX clinical response in patients with rheumatoid arthritis. The results suggest that ozone can probably increase the MTX efficacy because both share common therapeutical targets. The treatment with ozone can be a complement in the treatment of rheumatoid arthritis.

Pain (McMaster and The intra-articular injection of dex- trose or ozone could significantly reduce the pain in patients with osteoarthrosis, improving their functional state.

However, there was no significant difference between the groups regarding the results.

The ozone effects reduce inflammation of the joints, the pro-inflammatory cytokines, TNF- $\alpha$ and the IL-1 $\beta$ transcriptions and the reestablishment of the redox cell balance. Group 4 (PG/PS+oxygen) did not show these effects. 
Table 1. Summary of the evaluated studies and their differences in the methodology and conclusions - continuation

\begin{tabular}{|c|c|c|c|c|}
\hline Authors & Type of studies & $\begin{array}{l}\text { Ozone concentra- } \\
\text { tion and volume }\end{array}$ & Parameters evaluated & Conclusions \\
\hline $\begin{array}{l}\text { Mishra } \\
\text { et al. }{ }^{21}\end{array}$ & $\begin{array}{l}\text { Randomized clinical trial with } 46 \text { patients } \\
\text { divided into } 3 \text { groups: } \\
\text { Ozone intra-articular Group, Methylpredni- } \\
\text { solone Group and, Ozone Group when me- } \\
\text { thylprednisolone failed. } \\
\text { Treatment time: } 3 \text { months. }\end{array}$ & $30 \mu \mathrm{g} / \mathrm{mL}, 10 \mathrm{~mL}$ & $\begin{array}{l}\text { WOMAC scale } \\
\text { MacNab Criterion }\end{array}$ & $\begin{array}{l}\text { The group that received ozone had } \\
\text { a better result in the relief of pain, } \\
\text { stiffness and physical disability in } \\
\text { relation to the group that received } \\
\text { methylprednisolone. }\end{array}$ \\
\hline
\end{tabular}

PRP = platelet-rich plasma; WOMAC = Western Ontario and McMaster Universities Osteoarthritis Index; HA = hyaluronic acid; MTX = methotrexate. Source: Research data.

\section{DISCUSSION}

Aging is a reality all over the world, both in developed and developing countries, therefore, the legislation must guarantee the right of aging with the quality of life and functionality ${ }^{10}$. Among the most frequent diseases of the musculoskeletal system in the aged population in the world, osteoarthrosis outstands since it is the second more prevalent chronic disease among the elderly, only behind hypertensison ${ }^{11}$. So, with the increasing life expectancy of the population, the treatment of the degenerative joint diseases is of public health interest.

There is no acute data in Brazil about the prevalence of osteoarthrosis nor the estimated cost of the treatment and the social security expenditures resulting from osteoarthrosis complications. In the United States, in 2004, 86 billion dollars were directed to the treatment of osteoarthritis. The sales of drugs/supplements for osteoarthrosis was of 760 million dollars ${ }^{12}$.

Nevertheless, the clinical treatment of osteoarthritis is still cause of debate. Even after several years of research and investment, there are still questions about the optimal treatment.

Ozone therapy may be an integrative therapy, effective in the treatment of osteoarthrosis. In Brazil, the Federal Council of Medicine (CFM) does not recognize the ozone therapy yet. The Council allows the gas to be used in scientific research, according to Resolution 196/96 of the National Council of Health ${ }^{13}$, that rules the research involving human beings. The resolution includes the approval of the research project by the Research Ethics Committee (Report CFM number 13/09, ozone therapy is an experimental procedure submitted to the norms of Resolution CNS \# 196/96, 2009) ${ }^{14}$. In 2006, ABOZ (Brazilian Association of Ozone Therapy) was founded in Brazil aiming at legalizing the ozone therapy. In 2017, the Senate approved the Bill of Law number 227 that authorizes the prescription of ozone therapy nationwide, and now it is to be voted at the House of Representatives ${ }^{15}$. The CFM, under Order 073/17 ${ }^{16}$, invited $\mathrm{ABOZ}$ members to attend to the analysis process of ozone therapy ${ }^{16}$. In 2018, in the $1^{\text {st }}$ International Congress of Integrative Practices and Public Health (INTERCONGREPICS), the Brazilian Department of Health included the ozone therapy as an integrative practice and complementary of the Unified Health System (SUS). These treatments use therapeu- tical resources based on traditional knowledge and considering all the practices; it is estimated that about 5 million people, per year, benefit from this policy ${ }^{17}$.

Among 9 articles founded regarding ozone therapy in osteoarthrosis, 7 of them clearly showed the benefits of ozone in prospective study ${ }^{3}$; comparing the efficacy of ozone with placebo ${ }^{18}$; or in association with conventional treatments, as methotrexate $^{19}$, peptidoglycan-polysaccharide (PG/PS) ${ }^{20}$, methylprednisolone $^{21}$, and celecoxib and glucosamine ${ }^{22}$.

In a study that evaluated 220 patients treated with $20 \mu \mathrm{g} / \mathrm{mL}$ of ozone, twice a week during 3 years, it proved the analgesic effect of the ozone injection in the osteoarthrosis of the joint and the spine ${ }^{3}$. Pain relief, improvement in stiffness, physical disability, and functional improvement and the quality of life were observed with the use of ozone compared to methylprednisolone ${ }^{21}$ in patients with osteoarthritis of the $\mathrm{knee}^{18}$, in patients with mild to moderate osteoarthritis with the ozone intra-articular injection $^{18,21,22}$.

Patients with rheumatoid arthritis that used ozone (rectal route) increased the MTX clinical response and efficacy, probably because both share common therapeutical targets ${ }^{19}$.

In the studies where no benefits were observed, two of them compared ozone with $\mathrm{PRP}^{23,24}$. However, they do not mention the ozone concentrations used, which might have influenced the negative result ${ }^{23}$. Moreover, PRP is considered a promising advance regarding the time for tissue regeneration, which can limit the comparison with ozone. However, PRP requires care in the manipulation of blood and it is an invasive therapy since the patient has to present a stable clinical picture to collect about $500 \mathrm{~mL}$ of blood for the PRP, and its cost is around 3 thousand reais for each application ${ }^{25}$. On the other hand, the ozone therapy requires smaller volumes of blood than PRP and it costs less. Moreover, less invasive routes than the intra-articular can be selected, such as the rectal route.

Unlike the lungs and the eyes that are very sensitive to ozone for having a low percentage of antioxidants, the blood has a higher limit of toxicity, being easier to work ${ }^{6}$.

Hashemi et al. ${ }^{26}$ also observed no benefits of ozone in relation to dextrose. However, it may not have been observed because the WOMAC scale that is worldwide accepted and more effective and known for joint diseases, was not used. 
There are divergences in the literature about the therapeutical ozone concentrations and the adverse effects. However, it is known that to avoid toxicity; ozone must be carefully controlled and used ${ }^{6}$.

Ozone concentrations vary from $20 \mu \mathrm{g} / \mathrm{m}^{18}$; others from $25 \mathrm{mg} / \mathrm{L}$ to $40 \mathrm{mg} /{ }^{19}$. The intra-articular and rectal insufflation routes have shown benefits in the treatment of osteoarthritis with the use of ozone.

The studies that used a lower dose, of about $20 \mu \mathrm{g} / \mathrm{mL}$ to $30 \mu \mathrm{g} /$ $\mathrm{mL}^{3,21,22,24}$, intra-articular route, showed significant difference among treatments, in favor of ozone.

Only one study used a higher dose, $15 \mathrm{~g} / \mathrm{mL}$ intra-articular route, and no ozone benefits have been observed ${ }^{26}$.

The frequency was, on average, 1 to 3 times per week ${ }^{3,20,26}$. The time of the assessments varied from 21 days ${ }^{19}$ by the rectal route to 12 months $^{24}$ by intra-articular route. Moreover, in most of the studies, the treatment time was of 3 to 4 months ${ }^{3,18,21,22}$.

The study that lasted only 24 days $^{20}$ was conducted in rats. The study ${ }^{19}$ that evaluated for only 21 days used ozone (rectal route) associated with other drugs such as anti-inflammatories, which should not be used for long periods, which explains the short period.

Concentrations of about $20 \mu \mathrm{g} / \mathrm{mL}$ to $40 \mathrm{mg} / \mathrm{L}$, during 3 to 4 months show the efficacy and benefits of ozone ${ }^{3,18,21,22}$.

In this sense, we notice the need of regulation of the ozone therapy, not only for the treatment of osteoarthrosis but also of other diseases to define the effective concentration as well as the treatment time. With the regulation of the procedure, other niches of research emerge, as, ozonizer machines and ozone concentration meters in different fluids (air, blood, oil, among others).

\section{CONCLUSION}

Ozone provides clinically relevant benefits that support its use for analgesic effect, relief of pain, stiffness, and physical disability, to reduce joint inflammation and to improve the quality of life in patients with osteoarthritis. The administration route can be both intra-articular and rectal, and in association with other drugs commonly used in the treatment of osteoarthritis. However, further studies are necessary to clarify and to standardize the concentrations that should be used, the frequency of application, and the adequate treatment duration.

The ozone therapy in osteoarthrosis is an integrative, low-cost and effective therapy that should be implemented in the Public Health Service, given the prevalence of the disease.

\section{REFERENCES}

1. Salter RB. Distúrbios e lesões do sistema musculoesquelético. Rio de Janeiro: Medsi; 2001. 699p.

2. Falzoni W. O ozônio: ozonioterapia: um "novo” tratamento, com uma longa tradição. In: $1^{\circ}$ Congresso Internacional de Ozonioterapia, Belo Horizonte, MG [acesso em 25 jul 2017]. Disponível em: http://www.ozonioterapiamedica.com.br/o-ozonio.html.

3. Al-Jaziri AA, Mahmoodi SM. Efeito analgésico da injeção de oxigênio do ozônio na osteoartrite da coluna e da articulação. Saudi Med J. 2008;29(4):553-7.

4. Bocci V, Aldinucci C. Biochemical medications induced in human blood by oxygenation-ozonation. J Biochem Mol Toxicol. 2006;20(3):133-8.

5. Val RC, Silva RC, Nunes TA, Souza TK. O papel da oxigenoterapia hiperbárica na doença vascular periférica. J Vasc Bras. 2003;2(3):171-6.

6. Bocci VA. Scientific and medical aspects of ozone therapy. State of the art. Arch Med Res. 2018;37(4):425-35.

7. Anagha VS, Arun VS, Digamber MS, Swati VP, Mahesh SC, Mrinal VS, et al. Ozone therapy: healing properties of the blue gas. Int J Oral Health Dentistry. 2016;2(1):35-8.

8. Rapposelli D. Ozone safe, effective for knee osteoarthritis pain. 2017. [acesso em $5 \mathrm{ab}$ 2018]. Disponível em: https://www.clinicalpainadvisor.com/arthritis/intra-articular-ozone-injections-shown-to-be-beneficial-for-knee-oa-pain/article/684149/).

9. Elvis AM, Ekta JS. Ozone therapy: a clinical review. J Nat Sc Biol Med. 2011;2(1):66-70.

10. de la Fuente J, Santiago J, Román A, Dumitrache C, Casasanto D. When you think about it, your past is in front of you: how culture shapes spatial conceptions of time. Psychol Sci. 2014;25(9):1682-90.

11. Lebrão ML, Laurenti R. Condiçôes de saúde. In: Lebrão ML, Duarte, YAO, organizador. O Projeto SABE no Município de São Paulo: uma abordagem inicial. Brasília: OPAS/MS; 2003. 75-91p.

12. Senate. Committee on health, education, labor and pensions. Subcommittee on aging (United States of American). Arthritis: a national epidemic: hearing before the subcommittee on aging of the committee on health, education, labor and pensions United States Senate one hundred eighth congress. Washington: Committee on Health, Education, Labor and Pensions; 2005.

13. Conselho Nacional de Saúde (Brasil). Resolução no 196, de 16 de outubro de 1996 Aprova as diretrizes e normas regulamentadoras de pesquisas envolvendo seres humanos. Diário Oficial da União 1996; seçâo1.

14. Conselho Federal de Medicina (Brasil). Parecer n ${ }^{\circ} 13$, de 9 de julho de 2009. A ozonioterapia é procedimento experimental submetido às normas da Resolução CNS no 196/96. Diário Oficial da União; seçăo 1, 2009.

15. Senado Federal (Brasil). Projeto de Lei do Senado n ${ }^{\circ} 227$, de 2017. Autoriza a prescriçáo da Ozonioterapia em todo o território nacional [acesso em 18 ago 2017]. Disponível em: https://www25.senado.leg.br/web/atividade/materias/-/materia/130041.

16. Conselho Federal de Medicina (Brasil). Despacho Cojur no 073, de 1 de janeiro de 2017. Ofício 001/2017 - Solicitação de Participação de membros da ABOZ no processo de análise da Ozonioterapia [acesso em 18 ago 2017]. Disponível em: http:// portal.cfm.org.br/index.php?option=com_normas.

17. Valadares C. Ministério da Saúde inclui 10 novas práticas integrativas no SUS. Brasília, DF; 2018. [acesso em 5 abr 2018]. Disponível em: http://portalms.saude.gov.br/ noticias/agencia-saude/42737-ministerio-da-saude-inclui-10-novas-praticas-integrativas-no-sus.

18. Lopes de Jesus CC, Dos Santos FC, de Jesus LM, Monteiro I, Sant'Ana MS, Trevisani VF. Comparison between intra-articular ozone and placebo in the treatment of knee osteoarthritis: a randomized, double-blinded, placebo-controlled study. PLoS One. 2017;12(7):e0179185.

19. León Fernández OS, Viebahn-Haensler R, Cabreja GL, Espinosa IS, Matos YH, Roche LD, et al. Medical ozone increases methotrexate clinical response and improves cellular redox balance in patients with rheumatoid arthritis. Eur J Pharmacol. 2016;789:313-8.

20. Vaillant JD, Fraga A, Díaz MT, Mallok A, Viebahn-Hänsler R, Fahmy Z, et al. Ozone oxidative postconditioning ameliorates joint damage and decreases pro-inflammatory cytokine levels and oxidative stress in PG/PS-induced arthritis in rats. Eur J Pharmacol. 2013;714(1-3):318-24.

21. Mishra SK, Pramanik R, Das P, Das PP, Palit AK, Roy J, et al. Role of intra-articular ozone in osteo-arthritis of knee for functional and symptomatic improvement. IJPMR. 2011;22(2):65-9.

22. Feng X, Beiping L. Therapeutic efficacy of ozone injection into the knee for the osteoarthritis patient along with oral celecoxib and glucosamine. J Clin Diagn Res. 2017;11(9):UC01-UC03.

23. Shen L, Yuan T, Chen S, Xie X, Zhang C. The temporal effect of platelet-rich plasma on pain and physical function in the treatment of knee osteoarthritis: systematic review and meta-analysis of randomized controlled trials. J Orthop Surg Res. 2017;12(16):1-12

24. Duymus TM, Mutlu S, Dernek B, Komur B, Aydogmus S, Kesiktas FN. Choice of intra-articular injection in treatment of knee osteoarthritis: platelet-rich plasma, hyaluronic acid or ozone options. Knee Surg Sports Traumatol Arthrosc. 2017;25(2):485-92.

25. Costa PA, Santos P. Platelet-rich plasma: a review of its therapeutic use. RBAC. 2016;48(4).

26. Hashemi M, Jalili P, Mennati S, Koosha A, Rohanifar R, Madadi F, et al. The effects of prolotherapy with hypertonic dextrose versus prolozone (intraarticular ozone) in patients with knee osteoarthritis. Anesth Pain Med. 2015;5(5):e27585. 